\title{
ANALISA PEMANFAATAN TURBIN VENTILATOR SEBAGAI SUMBER LISTRIK SKALA RUMAH TANGGA DENGAN KAPASITAS $900 \mathrm{~W}$
}

\author{
Ellysa Kusuma Laksanawati, Efrizal, Miftakhul Rohman \\ Program Studi Teknik Mesin, Fakultas Teknik, Universitas Muhammadiyah Tangerang \\ Jl. Perintis Kemerdekaan I, No. 33, Cikokol, Tangerang, Banten 15118, Indonesia \\ E-mail :efrizal.arifin@gmail.com dan mr.miftakh@gmail.com
}

\begin{abstract}
ABSTRAK
Pemanfaatan energi terbarukan di Indonesia saat ini sedang dikembangkan untuk menggantikan energi konvensional hal ini dikarenakan menipisnya cadangan energi fosil di Indonesia. Melalui Peraturan Presiden Nomor 05 tahun 2006 tentang Kebijakan Energi Nasional (KEN) telah menetapkan target pemanfaatan energi baru dan terbarukan (EBT) sebesar 25\% pada tahun 2025. Energi angin adalah salah satu bentuk energi alternatif yang dapat dimanfaatkan sebagai energi mekanik oleh turbin angin untuk diubah menjadi energi listrik oleh generator. Turbin ventilator mampu berputar selama 24 jam berfungsi seabagai kipas hisap, biasanya digunakan diatap pabrik, gudang, gedung olahraga dan sebagainya. Penelitian ini mencoba memanfaatkan turbin ventilator sebagai sumber listrik skala rumah tangga dengan kapasitas 900 Watt. Dari hasil penelitian ini turbin ventilator dapat digunakan sebagai sumber listrik dengan daya 5,57 Watt. Untuk memenuhi kebutuhan listrik skala rumah tangga dengan kapasitas 900 Watt generator yang dibutuhkan mempunyai output arus $36 \mathrm{~A}$ tegangan $12 \mathrm{~V}$ untuk mensuplai baterai $12 \mathrm{~V} 60 \mathrm{Ah}$ selama 2 jam dengan lama pemakaian 38,4 menit.
\end{abstract}

\section{PENDAHULUAN}

Kebutuhan energi di Indonesia khususnya dan di dunia pada umumnya terus meningkat karena pertambahan penduduk, pertumbuhan ekonomi dan pola konsumsi energi itu sendiri yang senantiasa meningkat. Salah satu sumber pemasok listrik, PLTA bersama pembangkit listrik tenaga uap (PLTU) dan pembangkit listrik tenaga gas (PLTG) memang memegang peran penting terhadap ketersediaan listrik. Indonesia adalah negara yang memiliki sumber daya energi yang sangat melimpah, salah satunya adalah sumber energi angin. Indonesia yang merupakan negara kepulauan dan salah satu Negara yang terlatak di garis khatulistiwa merupakan faktor, bahwa Indonesia memiliki potensi energi angin yang melimpah.

Turbin angin adalah alat yang berfungsi untuk mengubah energi kinetik angin menjadi energi listrik. Energi angin dikonversi menjadi energi putar oleh rotor yang akan memutar generator, dengan atau tanpa adanya roda gigi. Energi putar tersebut kemudian dikonversi menjadi energi listrik sesuai dengan hukum Faraday.

Turbin ventilator merupakan turbin dengan sumbu vertikal yang memilki dua fungsi yaitu sebagai turbin angin dan kipas hisap. Turbin ventilator menggunakan energi angin sebagai pengerak turbin ventilasi. Alat ini sering digunakan diatap bangunan yang berfungsi sebagai ventilasi bangunan perumahan dan industri.

Energi surya dapat menghasilkan daya hingga 156.486 MW, jumlah yang lebih besar jika dibandingkan dengan sumber energi terbarukan yang lainnya. Indonesia merupakan negara yang terletak dalam jalur khatulistiwa yang sepanjang tahun mendapatkan cahaya matahari yang berlimpah.

\section{METODE PENELITIAN}

\section{A. Desain Penelitian}

Dalam penelitian ini, metode yang digunakan adalah studi literatur (kepustakaan), melakukan eksperimen dan melakukan pengamatan tentang alat 
penyemprot.

Kemudian

perancangan pembuatan /perangkaian

dilakukan komponen-komponen alat. Setelah itu, dilakukan pengujian alat dan pengamatan parameter.

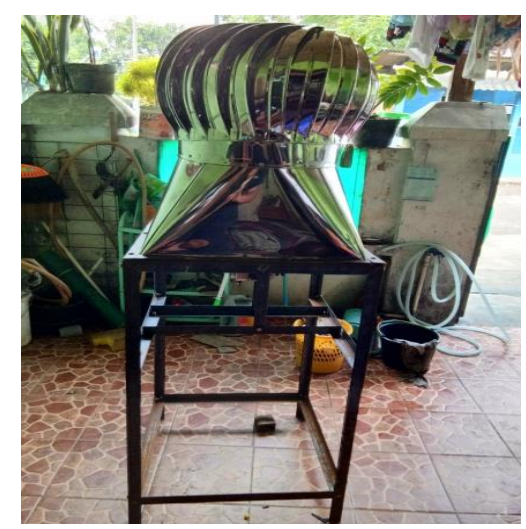

Gambar 1. Memodifikasi Turbin Ventilator

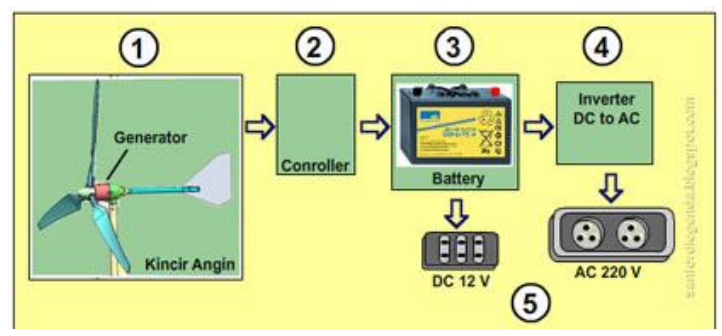

Gambar 2. Rangkaian Sistem Kelistrikan

Proses perakitan merupakan suatu proses penggabungan komponen-komponen mesin atau bahan menjadi suatu kesatuan dengan memperhatikan urutan yang telah ditentukan, sehingga menjadi sebuah mesin yang siap digunakan sesuai yang diperhitungkan dan tujuan yang telah direncanakan.

Langkah awal untuk melakukan perakitan adalah melakukan pengecekan komponen-komponen yang hendak dirakit, menyiapkan alat bantu dalam perakitan komponen-komponen serta mempersiapkan langkah-langkah perakitan. Dengan langkah perakitan yang tepat akan mempermudah dan mempercepat proses perakitan itu sendiri serta menjamin keberhasilan rancangan.

Ukur arus tegangan yang masuk ke baterai melalui terminal pada Charger
Controller. Pengukuran arus tegangan pada tiap posisi sudut arah mata angin.

1. Catat hasil pengukuran yang telah dilakukan untuk di masukan ke data Standart Test Condition.

2. Pengisian baterai, hal ini dilakukan bertujuan untuk mengetahui berapa lama waktu yang dibutuhkan untuk mengisi penuh daya baterai dengan menggunakan modul PV.

Turbin ventilator sangat cocok digunakan untuk berbagai jenis bangunan seperti pabrik, gudang, gedung olahraga, dapur, rumah tinggal, perkantoran, dan rumah makan. Gambar 3 merupakan contoh dari turbin ventilator yang biasa dipasang di atap gedung. Turbin ventilator yang digunakan memiliki dimensi diameter $66 \mathrm{~cm}=0,66 \mathrm{~m}$, tinggi $35 \mathrm{~cm}=0,35 \mathrm{~m}$, panjang celah sudu $7 \mathrm{~cm}=$ $0,07 \mathrm{~m}$, berat $4616 \mathrm{gr}=4,616 \mathrm{~kg}$ dan memiliki blade atau bilah sebanyak 26 buah.

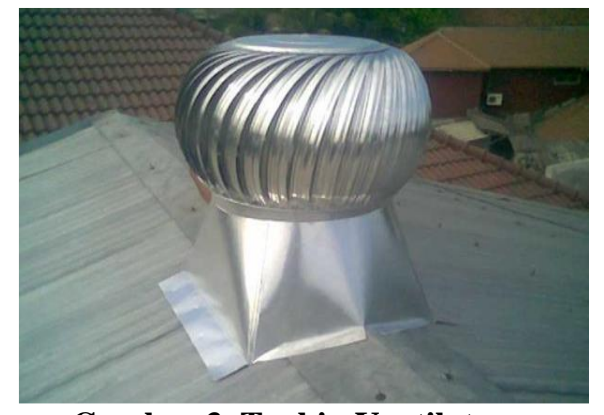

Gambar 3. Turbin Ventilator

\section{B. Metode Analisa Data}

Berikut adalah analisa dalam perakitan dan pengujian system :

Daya atau energi persatuan waktu dari angin dapat ditunjukan dengan persamaan :

$$
P_{t}=1 / 2 \rho A v^{3}
$$

Dimana:

$\mathrm{P}_{\mathrm{t}}$ : Daya angin (Watt)

$\mathrm{A}=$ Luas penampang angin/sirip $\left(\mathrm{m}^{2}\right)$

$=\pi r^{2}$

$v:$ Kecepatan angin $(\mathrm{m} / \mathrm{s})$

$\rho$ : Densitas udara ( $\rho$ rata-rata : 1,2 $\mathrm{kg} / \mathrm{m}^{2}$ )

Sedangkan daya yang dihasilkan turbin angin memenuhi persamaan : 


$$
\mathrm{P}_{1}=\mathrm{V} \mathrm{I}
$$

Dimana

$$
\begin{aligned}
& \mathrm{P}_{1}=\text { Daya listrik (Watt) } \\
& \mathrm{V}=\text { Tegangan (Volt) } \\
& \mathrm{I}=\text { Arus (Amper) }
\end{aligned}
$$

Perhitungan efisiensi turbin menggunakan persamaan :

$$
\text { Efisiensi }=\frac{P t}{P l} \times 100 \% \ldots(3)
$$

Untuk dapat menghitung diameter poros yang terdapat momen puntir/ twisting moment dapat diperoleh pada persamaan :

$$
\frac{\mathrm{T}}{\mathrm{J}}=\frac{\tau}{\mathrm{r}}
$$

Dimana :

$\mathrm{T}=$ Torsi pada poros $(\mathrm{Nm})$

$\mathrm{J}=$ momen inersia polar poros pejal

$$
=\frac{\pi}{32} d^{4}
$$

$\tau=$ tegangan puntir pada poros $\left(\mathrm{N} / \mathrm{m}^{2}\right)$

$\mathrm{r}=$ jari-jari poros $(\mathrm{m})$

Substitusikan persamaan (4) dan (5), maka :

$$
\mathrm{T}=\frac{\pi}{16} \tau d^{3}
$$

atau :

$$
d=\sqrt[3]{\frac{16 T}{\pi \tau}}
$$

Jika Poros Terdapat Momen Lentur

$$
\frac{\mathrm{M}}{\mathrm{J}}=\frac{\sigma_{\mathrm{b}}}{\mathrm{r}}
$$

Dimana :

$\mathrm{M}=$ Momen bending $(\mathrm{Nm})$

$\mathrm{J}=$ momen inersia polar poros pejal

$$
=\frac{\pi}{64} d^{4}
$$

$\sigma_{\mathrm{b}}=$ tegangan bending pada poros

$\left(\mathrm{N} / \mathrm{m}^{2}\right)$

$$
\mathrm{r}=\text { jari-jari poros }(\mathrm{m})
$$

Substitusikan persamaan (8) dan (9), maka :

atau :

$$
\mathrm{M}=\frac{\pi}{32} \sigma_{\mathrm{b}} d^{3}
$$

$$
d=\sqrt[3]{\frac{32 M}{\pi \sigma_{\mathrm{b}}}}
$$

Jika pada poros terdapat kombinasi antara momen lentur dan momen puntir maka perancangan poros harus didasarkan pada kedua momen tersebut. Besarnya tegangan geser maksimum pada poros dirumuskan :

$$
\tau_{\max }=\frac{1}{2} \sqrt{\sigma_{\mathrm{b}}^{2}+4 \tau^{2}}
$$

Substitusikan persamaan (6) dan (10), maka :

$$
\begin{array}{r}
\tau_{\max }=\frac{1}{2} \sqrt{\left(\frac{32 \mathrm{M}}{\pi \mathrm{d}^{3}}\right)^{2}+4\left(\frac{16 \mathrm{~T}}{\pi \mathrm{d}^{3}}\right)^{2}} \\
=\frac{16}{\pi \mathrm{d}^{3}} \sqrt{\mathrm{M}^{2}+\mathrm{T}^{2}} \ldots
\end{array}
$$

atau :

$$
d=\sqrt[3]{\frac{16 \sqrt{\mathrm{M}^{2}+\mathrm{T}^{2}}}{\pi \tau_{\max }}}
$$

Pernyataan $\sqrt{\mathrm{M}^{2}+\mathrm{T}^{2}} \quad$ dikenal sebagai equivalent twisting moment yang disimbolkan dengan $T_{e}$. $T_{e}$ dapat diartikan sebagai tegangan geser/ shear strees sebagai akibat adanya momen puntir pada suatu poros, mempunyai besar yang sama dengan moment puntir yang sebenarnya. Dengan demikian besarnya $\tau_{\max }$ sebanding dengan tegangan geser yang diizinkan $(\tau)$.

Tegangan geser yang diizinkan untuk pemakaian umum pada poros dapat diperoleh dari berbagai cara, salah satunya menggunakan perhitungan berdasarkan kelelahan puntir yang besarnya diambil $40 \%$ dari batas kelelahan tarik yang besarnya $45 \%$ dari kekuatan tarik.

Untuk pemilihan bahan poros yang digunakan di sini digunakan uji kekerasan Brinell yaitu menggunakan persamaan :

$$
H B=\frac{P}{(\pi D / 2)\left(D-\sqrt{D^{2}-d^{2}}\right)}=\frac{2 P}{(\pi D)\left(D-\sqrt{D^{2}-d^{2}}\right)}
$$

Untuk mengetahui jenis bahan serta kekuatan tarik bahan tersebut dapat menggunakan persamaan berikut ini.

$$
\sigma_{B}=0,345 \times H B \ldots \ldots . .(16)
$$

Besarnya tegangan geser maksimum yang terjadi pada poros utama mesin ini dapat dicari dengan menggunakan rumus (Sularso, 1984):

$$
\sigma_{s}=\frac{5,1}{d^{3}} \sqrt{(K b \cdot M b)^{2}+(K t \cdot T)^{2}} .
$$

Dimana :

$\mathrm{d}=$ diameter poros $(\mathrm{m})$

$\mathrm{Kb}=$ Faktor koreksi momen lentur $(1,5$

$-2,0)$

$\mathrm{Mb}=$ momen lentur (N.m)

Kt $=$ Faktor koreksi momen puntir

$(1,0-1,5)$ 
Karena poros tersebut berpasak maka untuk mencari tegangan geser bahan yang diijinkan $\left(\overline{\sigma_{s}}\right)$ dengan cara membagi kekuatan tarik bahan poros $\left(\sigma_{B}\right)$ dengan faktor koreksi keamanan, persamaan rumus (Sularso, 1985) :.

$$
\overline{\sigma_{s}}=\frac{\sigma_{B}}{S f_{1} \times S f_{2}} \ldots \ldots \ldots
$$

Dimana :

$$
\begin{aligned}
& \sigma_{\mathrm{b}}=\text { tegangan tarik bahan }(\mathrm{kg} \\
& \left.\qquad / \mathrm{mm}^{2}\right) \\
& \mathrm{Sf}_{1}=\text { faktor koreksi }(6) \\
& \mathrm{Sf}_{2}=\text { faktor koreksi }(1,3-3,0)
\end{aligned}
$$

Dalam perencanaan pasak, ada dua kemungkinan pasak tersebut rusak atau putus. Putus atau rusaknya pasak, ini disebabkan oleh :

1. Putus Akibat Adanya Gaya Geser

$$
\mathrm{F}=\mathrm{A} \cdot \tau_{g}
$$

Dimana :

$$
\begin{aligned}
& \text { A : Luas penampang putus } \\
& \text { tergeser }\left(\mathrm{mm}^{2}\right) \\
& \mathrm{A}: \mathrm{L} \cdot \mathrm{b} \\
& \mathrm{L}: \text { panjang pasak perancangan } \\
& (\mathrm{mm}) \\
& \mathrm{b}: \text { lebar pasak perancangan }(\mathrm{mm}) \\
& \tau_{g}: \text { tegangan geser yang diizinkan } \\
& \text { untuk bahan poros }\left(\mathrm{N} / \mathrm{mm}^{2}\right)
\end{aligned}
$$

Substitusikan pers (24) dan pers (25), maka :

$$
\begin{aligned}
& \frac{\mathrm{T}_{p}}{d / 2}=L \cdot b \cdot \tau_{g} \\
& T_{p}=L \cdot b \cdot \tau_{g} \cdot d / 2
\end{aligned}
$$

2. Putus Akibat Adanya Tekanan Bidang

$$
\mathrm{F}=\mathrm{A} \cdot \sigma_{b}
$$

Dimana :

A : Luas bidang pasak yang menekan/ bersinggungan terhadap bidang poros $\left(\mathrm{mm}^{2}\right)$

A $: \mathrm{L} . \mathrm{t} / 2$

L : panjang pasak perancangan (mm)

$\mathrm{t}$ : tinggi pasak perancangan $(\mathrm{mm})$

$\sigma_{b}$ : tegangan bidang yang diizinkan untuk bahan pasak $\left(\mathrm{N} / \mathrm{mm}^{2}\right)$

Substitusikan pers (24) dan pers (27), maka :

$$
\begin{aligned}
& \frac{\mathrm{T}_{p}}{d / 2}=L \cdot t / 2 \cdot \sigma_{b} \\
& T_{p}=L \cdot t / 2 \cdot \sigma_{b} \cdot d / 2
\end{aligned}
$$

Untuk menghitung kecepatan linier sabuk dapat dicari dengan menggunakan rumus (Khurmi dan Gupta,2005):

$$
\mathrm{V}=\frac{\pi \cdot d 1 \cdot n 1}{60}
$$

Keterangan :

$$
\begin{aligned}
& V=\text { kecepatan linear sabuk }(\mathrm{m} / \mathrm{s}) \\
& \mathrm{d}_{1}=\operatorname{diameter} \text { poros motor }(\mathrm{m}) \\
& \mathrm{n}_{1}=\text { putaran motor listrik }(\mathrm{rpm})
\end{aligned}
$$

Berdasarkan jari-jari pulley yang digunakan serta jarak antara sumbu poros motor listrik dan poros speed reducer maka kebutuhan panjang sabuk dapat dicari dengan menggunakan persamaan rumus (Khurmi dan Gupta,2005):

$$
\mathrm{L}=\frac{\pi}{2}\left(\mathrm{~d}_{2}+\mathrm{d}_{1}\right)+2 \mathrm{x}+\frac{\left(\mathrm{d}_{2}-\mathrm{d}_{1}\right)^{2}}{4 \mathrm{x}}
$$

Luas penampang sabuk dapat dihitung dengan menggunakan persamaan sebagai berikut rumus (Khurmi dan Gupta,2005)::

$$
A=b \times t
$$

Dimana :

$$
\begin{aligned}
& A=\text { luas penampang sabuk }\left(\mathrm{mm}^{2}\right) \\
& b=\text { lebar panampang sabuk } A(\mathrm{~mm}) \\
& t=\text { tebal sabuk } A(\mathrm{~mm})
\end{aligned}
$$

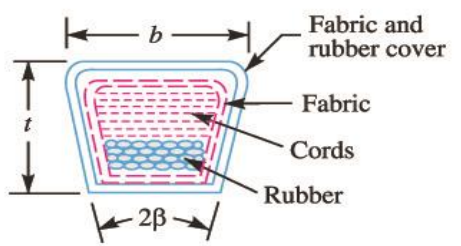

\section{Gambar 4. Sabuk/ Belt}

a) Tegangan Sisi Kendor $\left(\mathrm{T}_{2}\right)$ Dan Sisi Kencang $\left(\mathrm{T}_{1}\right)$

Massa dari permeter sabuk adalah :

$\dot{\mathrm{m}}=\mathrm{A} . \mathrm{L} \cdot \rho$

Dimana :

$\mathrm{A}=$ luas penampang sabuk $\left(\mathrm{mm}^{2}\right)$

$\mathrm{L}=$ panjang 1 meter length $(\mathrm{mm})$

$\rho=$ density bahan sabuk $\left(\frac{\mathrm{kg}}{\mathrm{m}^{3}}\right)$ 
Tegangan sentrifugal sabuk adalah :

$$
\mathrm{Tc}=\dot{\mathrm{m}} \mathrm{x} \mathrm{v}^{2}
$$

Dimana :

$$
\mathrm{v}=\text { kecepatan linier sabuk }(\mathrm{m} / \mathrm{s})
$$

Tekanan maksimum sabuk adalah :

$$
\mathrm{T}_{\max }=\sigma \mathrm{xA}
$$

Dimana :

$\mathrm{T}_{\max }$ : Gaya tegang maksimal $(\mathrm{Kg})$

$\sigma \quad$ : Tegangan tarik ijin sabuk, untuk sabuk dari bahan karet adalah $4-5 \mathrm{~N} / \mathrm{mm}^{2}$

A : Luas penampang sabuk $\left(\mathrm{mm}^{2}\right)$

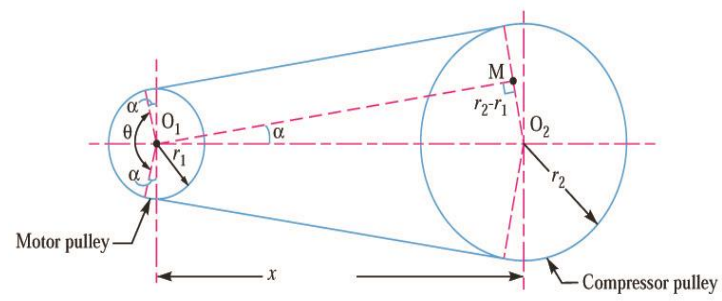

Gambar 5. Jarak Antar Pulli

Tegangan sisi kencang sabuk adalah :

$$
T_{1}=\mathrm{T}_{\max }-\mathrm{Tc}
$$

Tegangan sisi kendor sabuk adalah :

$$
\begin{aligned}
& \sin \alpha=\frac{\left[r_{2}-r_{1}\right]}{x} \\
& \theta=180^{0}-2 \alpha
\end{aligned}
$$

Analisa yang terjadi adalah sebagai berikut :

$$
\log \left[\frac{T_{1}}{T_{2}}\right]=\mu \cdot \theta \cdot \operatorname{cosec} \beta
$$

Dimana :

$$
\begin{aligned}
& \mathrm{r}_{2}=\text { jari }- \text { jari pulli yang } \\
& \text { digerakkan }(\mathrm{mm}) \\
& \mathrm{r}_{1}=\text { jari }- \text { jari pulli penggerak }(\mathrm{mm}) \\
& \mathrm{x}=\text { jarak antara pulli penggerak dan } \\
& \text { digerakkan }(\mathrm{mm}) \\
& \mu=\text { coeffisien of friction belt }
\end{aligned}
$$

\begin{tabular}{|c|c|c|c|c|c|c|c|c|c|c|c|c|}
\hline & \multicolumn{2}{|c|}{13.00} & \multicolumn{2}{|c|}{14.00} & \multicolumn{2}{|c|}{15.00} & \multicolumn{2}{|c|}{16.00} & \multicolumn{2}{|c|}{17.00} & \multirow[t]{2}{*}{ Rata } & \multirow{2}{*}{$\begin{array}{c}\text { Rata } \\
2 \\
\mathrm{Kec}\end{array}$} \\
\hline & $\mathrm{Kec}$ & $\mathrm{Rpm}$ & $\mathrm{Kec}$ & $\mathrm{Rpm}$ & $\mathrm{Kec}$ & Rpm & Kec & Rpm & $\mathrm{Kec}$ & Rpm & & \\
\hline 28,08 & 2,8 & 712,7 & 2,66 & 677,1 & 4,2 & 1069 & 3,36 & 855,3 & 2,1 & 534,6 & 769,7 & 3,024 \\
\hline 29108 & 2,1 & 534,6 & 2,8 & 712,7 & 4,06 & 1033 & 4,2 & 1069 & 2,52 & 641,5 & 798,2 & 3,136 \\
\hline & & & & & & & & & & & & \\
\hline $30: 09$ & 1,26 & 320,7 & 3,36 & 855,3 & 4,9 & 1247 & 2,1 & 534,6 & 2,66 & 677,1 & 726,9 & 2,856 \\
\hline & & & & & & & & Rata-Ra & a Kese & uruhan & 764,9 & 3,005 \\
\hline
\end{tabular}

Daya yang ditransmisikan oleh sabuk adalah :

$$
\mathrm{P}=(\mathrm{T} 1-\mathrm{T} 2) . \mathrm{v}
$$

\section{HASIL ANALISA DAN PEMBAHASAN}

Dalam penelitian ini pengukuran di lakukan untuk mengetahui besar kecepatan angin. Data tersebut sebagai berikut : dengan persamaan :
Tabel 1. Data Pengukuran Angin

Perhitungan energi yang dihasilkan oleh energi angin, memenuhi persamaan klasik mengenai energi kinetik, udaara yang bergerak dikonversi menjadi energi listrik melalui turbin. Sehingga daya atau energi persatuan waktu dari angin dapat ditunjukan

$$
\begin{aligned}
\mathrm{P}_{\mathrm{t}}= & \frac{1}{2} \mathrm{X} 1,2 \frac{\mathrm{kg}}{\mathrm{m}^{2}} \mathrm{X}\left(3,14 \mathrm{X}(0,33)^{2} \mathrm{~m}^{2}\right. \\
& \mathrm{X} 3,005^{3} \frac{\mathrm{m}^{3}}{\mathrm{~s}^{3}} \\
= & 5,57 \frac{\mathrm{kg}}{\mathrm{s}^{3}} \mathrm{~m}^{3} \cong 5,57 \text { watt }
\end{aligned}
$$

Besar torsi yang dihasilkan poros ventilator adalah :

$$
\begin{aligned}
\mathrm{T}=\frac{\mathrm{P} \cdot 60}{2 \pi \mathrm{N}} & =\frac{5,57 \text { watt. } 60}{2 \pi \mathrm{X} 764,9 \mathrm{rpm}} \\
& =0,069 \mathrm{Nm}
\end{aligned}
$$

Tabel 2. Harga Kekerasan Brinell Pada Bahan Poros

\begin{tabular}{|l|c|c|c|c|}
\hline No. & Bahan & $\begin{array}{c}\text { Diameter } \\
\text { indentasi } \\
(\mathrm{mm})\end{array}$ & $\begin{array}{c}\text { Harga kekerasan } \\
\text { Brinell } \\
\left(\mathrm{kg} / \mathrm{mm}^{2}\right)\end{array}$ & $\begin{array}{c}\text { Rata- } \\
\text { rata } \\
(\mathrm{kg} / \mathrm{m} \\
\left.\mathrm{m}^{2}\right)\end{array}$ \\
\hline 1. & Poros & 1,325 & 540,50 & 540,4 \\
2. & Poros & 1,295 & 540,91 & 8 \\
\hline 3. & Poros & 1,360 & 540,02 & \\
\hline
\end{tabular}

Dengan memasukkan harga kekerasan brinell rata-rata ke dalam persamaan rumus (2.13) di atas maka diperoleh harga kekuatan tarik bahan poros tersebut.

$$
\begin{aligned}
\sigma_{\mathrm{B}} & =0,345 \times \mathrm{HB} \\
& =0,345 \times 540,48 \mathrm{~N} / \mathrm{mm}^{2} \\
& =186,46 \mathrm{~N} / \mathrm{mm}^{2}
\end{aligned}
$$

Berdasarkan hitungan di atas bahan tersebut mempunyai kekuatan tarik sebesar 186,46 $\mathrm{N} / \mathrm{mm}^{2}$. Berdasarkan klasifikasi baja karbon, bahan tersebut digolongkan sebagai baja karbon medium (mild steel). Berdasarkan tabel baja konstruksi umum menurut DIN 
17100 (terlampir) bahan tersebut digolongkan ke dalam baja $S T$ 60. dengan No. Bahan 1,0540 dan Jenis Baja Fe60-1 (Euronoom 25). Bahan ini dapat diketahui sifat mekanis melalui tegangan tariknya dan sifat-sifat penting yang berpengaruh pada lingkungan. Bahan poros ini keras, ulet, mampu mesin, tangguh, mampu las, tahan terhadap torsi, dan tahan karat.

Pada perencanaan, poros ventilator berupa poros pejal, adapun dalam menentukan besarnya poros sesuai persamaan:

$$
\begin{aligned}
d & =\sqrt[3]{\frac{16 T}{\pi \tau}} \\
& =\sqrt[3]{\frac{16 X 69 \mathrm{Nmm}}{\pi X 60 \mathrm{~N} / \mathrm{mm} 2}} \\
& =14,35 \mathrm{~mm}
\end{aligned}
$$

Dalam perencanaan, besar torsi yang terjadi pada poros harus lebih besar dari torsi yang dipindahkan. Analisa sebagai berikut :

$$
\begin{aligned}
\mathrm{Tp} & =\mathrm{k} \times \mathrm{T} \\
& =1,25 \times 0,069 \mathrm{Nm} \\
& =0,086 \mathrm{Nm}
\end{aligned}
$$

Pada perencanaan pasak tersebut diatas, di perkirakan pada pasak tersebut akan terjadi 2 hal, yaitu :

a. Pasak Akan Putus Terhadap Gaya Gesek

Dengan asumsi ini, maka pasak akan mengalami gaya keliling, ini terjadi karena poros berputar. Maka panjang pasak yang diperlukan adalah sebagai berikut :

$$
\begin{aligned}
\mathrm{L} & =\frac{2 \times 86 \mathrm{Nmm}}{5 \mathrm{~mm} \times 42 \frac{\mathrm{N}}{\mathrm{mm}^{2}} \times 12 \mathrm{~mm}} \\
& =0,07 \mathrm{~mm}
\end{aligned}
$$

b. Pasak Akan Rusak Akibat Tekanan Bidang

Berdasarkan asumsi tersebut, maka panjang pasak yang diperlukan adalah sebagai berikut :

$$
\begin{aligned}
\mathrm{L} & =\frac{4 \times 86 \mathrm{Nmm}}{5 \mathrm{~mm} \times 70 \frac{\mathrm{N}}{\mathrm{mm}^{2}} \times 12 \mathrm{~mm}} \\
& =0,08 \mathrm{~mm}
\end{aligned}
$$

Berdasarkan analisa panjang pasak pada point $\mathrm{a}$ dan $\mathrm{b}$ tersebut diatas, terdapat ukuran panjang pasak 0,07 $\mathrm{mm}$ dan $0,08 \mathrm{~mm}$. Untuk proses perancangan ini, diambil ukuran pasak $0,08 \mathrm{~mm}$ dengan alasan gaya akibat tekanan bidang lebih besar dibanding besarnya gaya yang akan memutuskan pasak.

Pada perencaan pulli dan ketersediaannya dipasaran, diambil ukuran pulli penggerak $177,8 \mathrm{~mm}$ sedangkan pulli yang digerakkan $50,8 \mathrm{~mm}$. Besarnya kecepatan dari pulli yang digerakkan adalah sebagai berikut :

$$
\begin{aligned}
\mathrm{n}_{3} & =\frac{1529,8 \mathrm{rpm} \times 177,8 \mathrm{~mm}}{50,8 \mathrm{~mm}} \\
& =5354,3 \mathrm{rpm}
\end{aligned}
$$

Dengan demikian, didapat kecepatan akhir pulli digerakkan sebesar 5354,3 rpm.

Pemilihan jenis sabuk disini adalah tipe A dengan ukuran lebar $12,5 \mathrm{~mm}$, tinggi $9 \mathrm{~mm}$ dan dengan sudut $2 \beta=40^{\circ}$. Jenis bahan sabuk adalah leatherl kulit. Perancangan sabuk, terdapat beberapa kategori sebagai analisa, yaitu :

a. Kecepatan Linier Sabuk

$$
\begin{aligned}
v & =\frac{\pi \times d_{1} \times n_{1}}{60} \\
v & =\frac{3,14 x 0,12 \mathrm{~mm} \times 1529,8 \mathrm{rpm}}{60} \\
& =9,61 \frac{\mathrm{m}}{\mathrm{s}}
\end{aligned}
$$

Adapun kecepatan linear sabuk yang diizinkan adalah sebesar $30 \mathrm{~m} / \mathrm{s}$ (Khurmi, 1984). Denga demikian perencanaan sabuk dikatakan aman, karena 9,61 m/s $<30 \mathrm{~m} / \mathrm{s}$.

b. Perhitungan Kebutuhan Panjang Sabuk$\mathrm{V}(\mathrm{V}$-Belt $)$

Berdasarkan jari-jari pulley yang digunakan serta jarak antara sumbu poros pulli penggerak dan yang digerakkan 100 $\mathrm{mm}$, maka kebutuhan panjang sabuk dapat dicari dengan menggunakan persamaan rumus (2.4).

$$
\begin{gathered}
\mathrm{L}=\frac{\pi}{2}\left(\mathrm{~d}_{2}+\mathrm{d}_{1}\right)+2 \mathrm{x}+\frac{\left(\mathrm{d}_{2}-\mathrm{d}_{1}\right)^{2}}{4 \mathrm{x}} \\
\mathrm{L}=\left[\frac{3,14}{2} \cdot(177,8+50,8)\right]+[2.100] \\
+\left[\frac{(177,8-50,8)^{2}}{4.100}\right] \\
=599,22 \mathrm{~mm}
\end{gathered}
$$

Berdasarkan ketersediaan sabuk/ belt dipasaran, maka hasil tersebut disesuaikan dengan table yang ada dipasaran 
(terlampir). Dari table tersebut didapat ukuran $610 \mathrm{~mm}$ dengan standar nominal sabuk dipasaran adalah sabuk dengan nomor 24.

c. Tegangan Sisi Kendor $\left(\mathrm{T}_{2}\right)$ Dan Sisi Kencang $\left(\mathrm{T}_{1}\right)$

Massa dari permeter sabuk adalah :

$\dot{\mathrm{m}}=0,009 \mathrm{~m} \times 0,0125 \mathrm{~m} \times 1 \times 1000 \frac{\mathrm{kg}}{\mathrm{m}^{3}}$

$$
=0,1125 \frac{\mathrm{kg}}{\mathrm{m}}
$$

Tegangan sentrifugal sabuk adalah :

$\mathrm{Tc}=0,1125 \frac{\mathrm{kg}}{\mathrm{m}} \times\left[8,79 \frac{\mathrm{m}}{\mathrm{s}}\right]^{2}=8,69 \mathrm{~N}$

Tekanan maksimum sabuk adalah :

$\mathrm{T}=\left[5 \frac{\mathrm{N}}{\mathrm{mm}^{2}}\right] \times[9 \mathrm{~mm} \times 12,5 \mathrm{~mm}]$

$$
=562,5 \mathrm{~N}
$$

$>$ Tegangan sisi kencang sabuk adalah :

$T_{1}=562,5 \mathrm{~N}-8,69 \mathrm{~N}=553,81 \mathrm{~N}$

$>$ Tegangan sisi kendor sabuk adalah :

$\sin \alpha=\frac{\left[\frac{177,8}{2}-\frac{50,8}{2}\right] \mathrm{mm}}{300 \mathrm{~mm}}=0,08$ maka $\alpha=$ $4,59^{\circ}$

$\theta=180^{\circ}-(2 \times 4,59)=170,82^{\circ} \cong$ $170,82^{\circ} \times \pi / 180^{\circ}=2,98 \mathrm{rad}$.

Analisa yang terjadi adalah sebagai berikut :

$\log \left[\frac{T_{1}}{T_{2}}\right]=1,33$ maka $\left[\frac{T_{1}}{T_{2}}\right]=21,4$

$T_{2}=25,88 \mathrm{~N}$

Daya yang ditransmisikan oleh sabuk adalah :

$$
\begin{aligned}
\mathrm{P} & =(\mathrm{T} 1-\mathrm{T} 2) \cdot \mathrm{v} \\
& =(553,81 \mathrm{~N}-25,88 \mathrm{~N}) \times 8,79 \frac{\mathrm{m}}{\mathrm{s}} \\
& =4640,50 \text { watt }
\end{aligned}
$$

Alat penyimpan energi berfungsi sebagai back-up power, digunakan untuk menyimpan sebagian energi yang dihasilkan pada saat terjadi kelebihan daya pada waktu turbin angin berputar kencang atau pada saat penggunaan daya menurun, alat penyimpan ini menggunakan Aki mobil 12 Volt 64 Ah.

Pada perencanaan, disini dibutuhkan untuk pemakaian listrik 900 Watt sebagai beban pemakaian. Dengan berasumsi aki dalam keadaan penuh, maka sesuai dengan persamaan:

$$
I=\frac{P}{V}=\frac{900 \mathrm{~W}}{12 \mathrm{~V}}=75 \mathrm{~A}
$$

Alam pemakaian aki, haruslah dikurangi dieffisiensi aki sebesar $20 \%$, ini bertujuan untuk umur aki itu sendiri. Untuk standar dieffisien aki sendiri maksimal sampai $20 \%$. Lama pemakaian untuk 1 buah aki sebesar $12 \mathrm{~V}$ 64Ah untuk pemakaian 900 Watt adalah sebagai berikut :

$$
\begin{aligned}
\text { Waktu Pemakaian }= & \mathrm{I}-(20 \% \mathrm{X} \mathrm{I}) \\
& =75 \mathrm{~A} \\
& -(20 \% \text { X } 75 \mathrm{~A}) \\
& =0,68 \mathrm{jam}
\end{aligned}
$$

Pemakaian ini sebanding dengan 40,8 menit. Untuk menghitung waktu pengisian aki, hal yang harus diperhatikan adalah dengan menentukan lama pengisian aki tersebut. Lama pengisian aki haruslah minimal 2 jam, itu sebagai perkiraan. Maka :

$$
I=\frac{\mathrm{I}_{\mathrm{t}}}{t}=\frac{64 \mathrm{Ah}}{2 \mathrm{~h}}=32 \mathrm{~A}
$$

Dengan demikian arus yang diperlukan untuk pengisian aki selama 2 jam adalah sebagai berikut :

$$
=32 \mathrm{~A}+(20 \% \mathrm{X} 32 \mathrm{~A})=38,4 \mathrm{~A}
$$

Charge yang dibutuhkan untuk mengisi aki 64Ah selama 2 jam adalah charge dengan spesifikasi :

$>$ Arus output sebesar 38,4 A

$>$ Output tegangan 13,8 Volt (tersedia di pasaran).

\section{KESIMPULAN}

Berdasarkan rumusan masalah pada peneltian ini dapat ditarik kesimpulan bahwa:

1. Cara untuk memanfaatkan turbin ventilator agar dapat digunakan sebagai sumber listrik ialah dengan cara memodifikasi putaran sirip pada ventilator dihubungkan dengan poros ventilator nantinya poros tersebut akan menggerakan poros rotor pada generator untuk menghasilkan energi listrik dan energi listrik tersebut akan disimpan pada baterai.

2. Besar daya listrik yang dapat dihasilkan oleh turbin ventilator berdasarkan hasil analisa secara teoritis ialah 5,57 W.

3. Waktu yang dibutuhkan untuk pengisian baterai $12 \mathrm{~V} 60 \mathrm{Ah}$ ialah selama 2 jam dengan lama pemakian 0,64 jam atau 38,4 
menit. Untuk memenuhi kebutuhan listrik rumah tangga dengan kapasitas 900 Watt, maka dibutuhkan generator dengan output arus sebesar 36 Ampere dengan tegangan 12 Volt (tersedia dipasaran).

4. Cara untuk memanfaatkan energi listrik yang dihasilkan turbin ventilator untuk memenuhi kebutuhan listrik skala rumah tangga dengan kapasitas $900 \mathrm{~W}$ ialah dengan cara merubah arus DC dari baterai menjadi arus AC mengggunakan rangkaian kelistrikan.

\section{DAFTAR PUSTAKA}

Ansel C. Ugural. . Mechanical Design: An Integrated Approach. McGraw-Hill Inc, New York , 2003

Boediono. Ekonomi Mikro. BPFE UGM, Yogyakarta, 1993

Cengel Yunus, Heat Transfer: A Practica Approach, Second Edition, Mc GrawHill, 2003

Ginting Rosnani. Perancangan Produk. Gtaha Ilmu. Yogyakarta. 2010

Khurmi, R. S., Gupta, J. K. Machine Design. Eurasia Publising House, New Delhi, 2005

Partadiredja, A. Pengantar Ekonomika. Fakultas Ekonomi Universitas Gadjah Mada. cetakan ke-9, Yogyakarta, 1996

Saito, S., \& Surdia, T. Pengetahuan Bahan Teknik. Pradnya Paramita, Jakarta, 2005

Saputro, A. Anggaran Perusahaan. Fakultas Ekonomi Universitas Gadjah Mada. Jilid kedua, cetakan ke-10, Yogyakarta, 2000

Shigley, J.E., Standard Handbook Of Machine Design, California, 2004

Sularso \& Kiyokatsu Suga. Dasar Perencanaan dan Pemilihan Elemen Mesin. Pradnya Paramita, Jakarta, 1985 